\title{
Catalytic Properties of NiX zeolites in the Presence of Cerium Additives
}

\author{
SHU-HUA CHIEN* and WAN-LAN CHIANG \\ Institute of Chemistry, Academia Sinica, Taipei 11529, Taiwan (R.O.C.) tel. (+886-2) 7821889, \\ fax. $(+886-2) 7831237$ and Department of Chemistry, National Taiwan University, Taipei \\ 10764, Taiwan (R.O.C.)
}

(Received 24 February 1989, revised manuscript received 4 December 1989)

\section{ABSTRACT}

Cerium-containing NiX zeolites were prepared by the method of incipient-wetness impregnation. The nickel dispersion and the catalytic properties of the prepared catalysts were dependent on the $\mathrm{Ce}^{3+}$-to- $\mathrm{Ni}^{2+}$ ratio in zeolites. In the presence of cerium additives, $\mathrm{NiX}$ zeolites are able to exhibit a remarkable increase in nickel dispersion, and an enhanced reactivity in carbon monoxide hydrogenation with a shift of the product selectivity to heavier hydrocarbons. The results can be ascribed to the presence of the highly polarizing $\mathrm{Ce}^{3+}$ ions which induced some kind of metal-support interactions and thus led to the greater reducibility of nickel, to more accessible sites for carhon monnxide adsorption and to a larger surface concentration of hydrogen, which enhanced the hydrogen-assisted carbon monoxide dissociation during carbon monoxide-hydrogen reactions. The $\mathrm{Ce}^{3+}$ cations acted not only as "chemical anchors" but also as catalyst promoters.

Key words: cerium, nickel, zeolites, carbon monoxide hydrogenation, selectivity $\left(\mathrm{C}_{2+}\right.$ hydrocarbons)

\section{INTRODUCTION}

Several experimental results have shown that the addition of second metal ions to oxide-supported metal catalysts can cause a synergistic effect in addition to having a dramatic influence on the surface metal dispersion and on the catalytic properties. Various mechanisms have been proposed, such as the formation of bimetallic alloys [1], dopant-induced metal-support interactions [2], the presence of chemical anchors [3,4] and strong metal-support interactions (SMSI) [5].

Addition of $\mathrm{Ce}^{3+}$ cations to ion-exchanged nickel zeolite catalysts has been reported to have a significant influence on nickel dispersion and the catalytic properties [4-10]. The suppression of hydrogen chemisorption and the en- 
hanced reactivity of $\mathrm{CO}$ hydrogenation due to the presence of cerium additives were proposed and discussed in terms of SMSI [5], the terminology for specifying the unique characteristics of the high-temperature reduced titania-supported noble metal catalysts [11].

The purpose of this study was to examine the influence of cerium additives on cerium-containing $\mathrm{NiX}$ zeolites which were prepared by the method of incipient-wetness impregnation. It was desired to elucidate whether the cerium ions acted as chemical anchoring sites for the effective nickel dispersion, or played a significant role in the metal-support interactions. The coincident effects on the properties of nickel catalysts were studied and are discussed.

The influence of cerium additives on the carbon monoxide hydrogenation was studied. The catalysts were characterized by volumetric hydrogen chemisorption, BET surface area determinations with nitrogen adsorption, powder $\mathrm{X}$-ray diffraction, $\mathrm{X}$-ray photoelectron spectroscopy, temperature-programmed reduction and desorption of hydrogen and an in situ infrared spectroscopic study of carbon monoxide adsorption.

\section{EXPERIMENTAL}

The zeolite-supported nickel catalysts employed were prepared by the incipient-wetness impregnation technique as described previously [12]. Ceriumcontaining nickel catalysts were prepared by co-impregnating $\mathrm{NaX}$ zeolites with aqueous solutions of $\mathrm{Ce}^{3+}$ and $\mathrm{Ni}^{2+}$ ions to incipient wetness. $\mathrm{NaX}$ zeolite ( surface area ca. $350 \mathrm{~m}^{2} / \mathrm{g}$ ) was obtained from Applied Science. Nickel nitrate, $\mathrm{Ni}\left(\mathrm{NO}_{3}\right)_{2} \cdot 6 \mathrm{H}_{2} \mathrm{O}$, was oblained from Ferak and cerium nitrate, $\mathrm{Ce}\left(\mathrm{NO}_{3}\right)_{3} \cdot 6 \mathrm{H}_{2} \mathrm{O}$, from Strem Chemical. The impregnated samples were subsequently dried at room temperature for 2 days and were placed in an oven at $110^{\circ} \mathrm{C}$ for several hours before being stored in a desiccator. The contents of metal or metal ions in each sample are reported in the notation of each catalyst, e.g., $5-10 \mathrm{Ni}-\mathrm{Ce} / \mathrm{X}$ represents $\mathrm{X}$-zeolite supported catalyst with 5 wt.- $\%$ of nickel and $10 \mathrm{wt} . \%$ of cerium.

Details of most of the experimental procedures were essentially the same as described previously [12]. In summary, the reactivity of carbon monoxide hydrogenation was measured in a steady-state flow-mode microreactor operating at atmospheric pressure with a hydrogen-to-carbon monoxide gas flow-rate ratio of 3 . The exit gases were analysed with an on-line Varian 3700 gas chromatograph with a $6 \mathrm{ft} . \times 1 / 8$ in. I.D. Porapak QS ( $80-100 \mathrm{mesh})$ column at $110^{\circ} \mathrm{C}$. A flame ionization detector was used. The peak area was determined with a Hewlett-Packard 3392A integrator. In general, the catalysts were reduced at $500^{\circ} \mathrm{C}$ for $3 \mathrm{~h}$ and the reaction temperature was maintained at $300^{\circ} \mathrm{C}$. The measurements of hydrogen chemisorption were conducted at ambient temperature by a conventional volumetric method in a glass system with the capability of achieving a vacuum of $10^{-6}$ Torr $(1$ Torr $=133.3 \mathrm{~Pa})$. 
The temperature-programmed reduction (TPR) profiles were monitored by thermal conductivity detection (TCD), with a mixed gas stream of hydrogen and argon $\left(\mathrm{H}_{2} / \mathrm{Ar}=1: 10\right.$, total flow-rate $\left.=25 \mathrm{~cm}^{3} / \mathrm{min}\right)$ as a carrier gas. The temperature-programmed desorption (TPD) of hydrogen was carried out in an argon stream (flow-rate $=30 \mathrm{~cm}^{3} / \mathrm{min}$ ) and monitored by TCD. Before taking the TPD measurement, the catalyst was activated in situ following the procedures as for the activity measurements, but was allowed to cool to room temperature under a hydrogen flow.

The surface area of each sample was determined following the BET method for nitrogen adsorption at $77 \mathrm{~K}$, the data being collected with a Micromeritics AccuSorb-2100E surface area analyser. The X-ray diffraction measurements were performed on a Rigaku D/Max-III diffractometer with nickel-filtered $\mathrm{Cu}$ $\mathrm{K} \alpha$ radiation. The particle sizes of metallic nickel were calculated from $\mathrm{X}$-ray line-broadening measurements using the Scherrer equation [13]. Surface analysis by X-ray photoelectron spectroscopy was performed on a VG VGS 2000 ESCA spectrometer.

In the infrared spectroscopic studies, the dried catalyst powder was pressed into a thin self-supporting wafer and then placed in a quartz high-vacuum IR cell. The cell, in which sodium chloride windows were attached to Cajon UltraTorr adapters with a Varian high-vacuum Torr Seal, is capable of achieving a vacuum of $10^{-5}$ Torr and designed to be easily attached to a vacuum line so that samples can be treated by a gas flow and allowed low-pressure gas adsorption. A thin self-supporting catalyst wafer $\left(20-30 \mathrm{mg} / \mathrm{cm}^{2}\right)$ was achieved by pressing the dried catalyst powder with a $20-\mathrm{mm}$ die under a pressure of 480 $\mathrm{kg} / \mathrm{cm}^{2}$. Infrared spectra were taken on a Bruker IFS-85 Fourier transform spectrometer.

\section{RESULTS AND DISCUSSION}

\section{Catalytic activity and selectivity for carbon monoxide hydrogenation}

The influence of cerium additives on the zeolite-supported nickel catalysts for carbon monoxide hydrogenation is summarized in Table 1; each catalyst was reduced in a hydrogen flow at $500^{\circ} \mathrm{C}$ for $3 \mathrm{~h}$, and the reactions of carbon monoxide hydrogenation were carried out at $300^{\circ} \mathrm{C}$ with a hydrogen-to-carbon monoxide flow-rate of 3 . The enhanced catalytic activity, except for $5-2.5 \mathrm{Ni}-$ $\mathrm{Ce} / \mathrm{X}$, and the significant increase in the selectivity to higher molecular weight hydrocarbons were evident with the presence of cerium additives. The results are in agreement with those reported by Sauvion et al. [5] for ion-exchanged catalysts. In the present studies, the catalytic activities were strongly dependent on the concentration of $\mathrm{Ce}^{3+}$ cations or the $\mathrm{Ce}^{3+}-$ to- $\mathrm{Ni}^{2+}$ ratio. Apparently, a higher concentration of $\mathrm{Ce}^{3+}$ ions or a higher $\mathrm{Ce}^{3+}-$ to- $\mathrm{Ni}^{2+}$ ratio correspond to a higher catalytic activity. The results might be ascribed to the intrinsic properties of $\mathrm{Ce}^{3+}$ cations as a catalyst promoter or the "chemical 
TABLE 1

Influence of cerium additives on the activities and selectivities of $X$-zeolite-supported nickel catalysts for $\mathrm{CO}-\mathrm{H}_{2}$ reactions

$\mathrm{H}_{2} / \mathrm{CO}$ flow rate ratio $=3$ at atmospheric pressure; reaction temperature $=300^{\circ} \mathrm{C}$.

\begin{tabular}{llllllllll}
\hline Catalyst $^{\mathrm{a}}$ & \multirow{2}{*}{$\begin{array}{l}\text { Activity } \\
\left(\mu \text { mol CO/s} \cdot \mathrm{g}_{\text {cat }}\right)\end{array}$} & \multicolumn{2}{l}{ Product (mol-\%) } \\
\cline { 3 - 11 } & & $\mathrm{CH}_{4}$ & $\mathrm{C}_{2} \mathrm{H}_{4}$ & $\mathrm{C}_{2} \mathrm{H}_{6}$ & $\mathrm{C}_{3} \mathrm{H}_{6}$ & $\mathrm{C}_{3} \mathrm{H}_{8}$ & $\mathrm{C}_{4}$ & $\mathrm{C}_{5}$ \\
\hline $5 \mathrm{wt}-\% \mathrm{Ni} / \mathrm{X}$ & 6.86 & 94.14 & 0.03 & 4.13 & 0.12 & 1.16 & 0.42 & - \\
$5-2.5 \mathrm{Ni}-\mathrm{Ce} / \mathrm{X}$ & 2.31 & 86.55 & 0.23 & 8.21 & 1.14 & 2.77 & 1.10 & - \\
$5-5 \mathrm{Ni}-\mathrm{Ce} / \mathrm{X}$ & 23.45 & 84.13 & 0.31 & 9.51 & 1.43 & 3.17 & 1.25 & 0.20 \\
$5-10 \mathrm{Ni}-\mathrm{Ce} / \mathrm{X}$ & 43.01 & 77.47 & 0.50 & 12.58 & 2.21 & 3.85 & 2.65 & 0.74 \\
\hline
\end{tabular}

${ }^{a}$ Each catalyst was reduced in hydrogen at $500^{\circ} \mathrm{C}$ for $3 \mathrm{~h}$.

\section{TABLE 2}

Effect of reduction temperature on the activities and selectivities of 5-5 $\mathrm{Ni}-\mathrm{Ce} / \mathrm{X}$ catalysts for $\mathrm{CO}-\mathrm{H}_{2}$ reactions

$\mathrm{H}_{2} / \mathrm{CO}$ flow-rate ratio $=3$ at atmospheric pressure; reaction temperature $=300^{\circ} \mathrm{C}$.

\begin{tabular}{llllllllll}
\hline $\begin{array}{l}\text { Reduction } \\
\text { temperature }\left({ }^{\circ} \mathrm{C}\right)\end{array}$ & $\begin{array}{l}\text { Activity } \\
\left(\mu \text { mol CO} / \mathrm{s} \cdot \mathrm{g}_{\text {cat }}\right)\end{array}$ & \multicolumn{7}{l}{ Product $(\mathrm{mol}-\%)$} & \\
\cline { 2 - 9 } & & $\mathrm{CH}_{4}$ & $\mathrm{C}_{2} \mathrm{H}_{4}$ & $\mathrm{C}_{2} \mathrm{H}_{6}$ & $\mathrm{C}_{3} \mathrm{H}_{6}$ & $\mathrm{C}_{3} \mathrm{H}_{8}$ & $\mathrm{C}_{4}$ & $\mathrm{C}_{5}$ \\
\hline 500 & 23.45 & 84.13 & 0.31 & 9.51 & 1.43 & 3.17 & 1.25 & 0.20 \\
425 & 38.33 & 83.64 & 0.27 & 9.89 & 1.24 & 3.48 & 1.26 & 0.22 \\
300 & 7.19 & 82.07 & 0.39 & 11.28 & 1.38 & 3.39 & 1.25 & 0.24 \\
\hline
\end{tabular}

anchoring" ability of the highly polarizing $\mathrm{Ce}^{3+}$ cations to achieve a good dispersion of the metallic nickel particles on the zeolites, as suggested by Sauvion et al. [5]. The lower activity of 5-2.5 Ni-Ce/X might possibly occur because most of the $\mathrm{Ce}^{3+}$ cations go into $\mathrm{S}_{\mathrm{I}}$ sites in the hexagonal prism during the dehydration or reduction processes [9] prior to acting as the anchoring sites for the nickel and therefore, as a consequence, no $\mathrm{Ce}^{3+}$ cations would act as a catalyst promoter. According to the performance of the $\mathrm{Ni}-\mathrm{Ce} / \mathrm{X}$ samples, prepared by incipient-wetness impregnation, it seems clear that the $\mathrm{Ce}^{3+}$ ions acted not only as catalyst promoters but also probably as the "chemical anchors".

It was also noticeable that the catalytic activity of the $\mathrm{Ni}-\mathrm{Ce} / \mathrm{X}$ catalyst for carbon monoxide hydrogenation was very dependent on the reduction temperature of the catalyst. Table 2 shows the effect of the reduction temperature of the catalyst on the catalytic activity and selectivity for carbon monoxide hydrogenation over the $5-5 \mathrm{Ni}-\mathrm{Ce} / \mathrm{X}$-zeolites. Reduction of the sample at $425^{\circ} \mathrm{C}$ led to a higher activity than that of samples reduced at 300 or $500^{\circ} \mathrm{C}$, while the 
product selectivities did not vary significantly with the reduction temperature. Details are discussed in the following section.

\section{Chemisorption of hydrogen and the particle size of nickel}

Tables 3 gives the hydrogen uptakes obtained from the volumetric hydrogen chemisorption measurements; the nickel particle size and the BET surface area of each reduced $\mathrm{Ni}-\mathrm{Ce} / \mathrm{X}$ catalyst are also tabulated. The catalysts were treated under the same conditions as for the activity measurements (referred to Tables 1 and 2), apart from the system being evacuated at the reduction temperature for several hours before cooling to room temperature for chemisorption measurements. The mean particle size of metallic $\mathrm{Ni}^{0}(\mathrm{~d})$ was determined from XRD line-broadening measurements using the Scherrer equation [13]:

$d=k \lambda / \beta \cos \theta$

where $\lambda$ is the $\mathrm{X}$-ray wavelength, $k$ is the particle size factor, taken as 0.89 , and $\beta$ is the full angular width at half-maximum intensity of the $\mathrm{Ni}(111)$ line. The surface area of each reduced sample was obtained by the BET method with nitrogen adsorption at $77 \mathrm{~K}$.

From the hydrogen uptakes of 5-5 Ni-Ce/X and 5-10 Ni-Ce/X, it was obvious that the addition of $\mathrm{Ce}^{3+}$ cations did not suppress, but significantly enhanced, the chemisorption of hydrogen. In addition, the amount of hydrogen chemisorbed seemed not to be affected by the reduction temperature, as can be seen from the results for the $5-5 \mathrm{Ni}-\mathrm{Ce} / \mathrm{X}$ sample. The results were different to those for ion-exchanged $\mathrm{Ni}-\mathrm{Ce} / \mathrm{X}$ samples [5] and impregnated $\mathrm{Ni}-\mathrm{Ce} /$ $\mathrm{SiO}_{2}$ catalysts [14]. In both instances, suppression of hydrogen chemisorption was significant owing to the presence of cerium ions.

TABLE 3

Characterization of catalysts by $\mathrm{H}_{2}$ chemisorption, X-ray diffraction and BET surface area of $\mathrm{N}_{2}$ adsorption

\begin{tabular}{lllcl}
\hline Catalyst & $\begin{array}{l}\text { Reduction } \\
\text { temperature } \\
\left({ }^{\circ} \mathrm{C}\right)\end{array}$ & $\begin{array}{l}\mathrm{H}_{2} \text { uptake } \\
\left(\mu \mathrm{mol} \mathrm{H} \mathrm{H}_{2} / \mathrm{g}_{\text {cat }}\right)\end{array}$ & $\begin{array}{l}\text { Particle size } \\
\text { of } \mathrm{Ni}(\mathrm{nm})\end{array}$ & $\begin{array}{l}\text { Specific } \\
\text { surface area } \\
\left(\mathrm{m}^{2} / \mathrm{g}_{\text {cat }}\right)\end{array}$ \\
\hline $5 \mathrm{wt.}-\% \mathrm{Ni} / \mathrm{X}$ & 500 & 10.59 & 14.2 & 330 \\
$5-2.5 \mathrm{Ni}-\mathrm{Ce} / \mathrm{X}$ & 500 & 8.95 & 9.7 & 330 \\
$5-5 \mathrm{Ni}-\mathrm{Ce} / \mathrm{X}$ & 500 & 30.47 & 5.1 & 327 \\
$5-10 \mathrm{Ni}-\mathrm{Ce} / \mathrm{X}$ & 500 & 21.36 & 7.2 & 265 \\
$5-5 \mathrm{Ni}-\mathrm{Ce} / \mathrm{X}$ & 500 & 30.47 & 5.1 & 327 \\
& 425 & 30.61 & 5.0 & 328 \\
& 300 & 30.06 & $<4$ & 320 \\
\hline
\end{tabular}


Comparison of $\mathrm{Ni}$ dispersion and TOF for $\mathrm{CO}-\mathrm{H}_{2}$ reactions based on the results of $\mathrm{CO}$ chemisorption (A) and XRD particle size calculation (B).

\begin{tabular}{|c|c|c|c|c|c|}
\hline \multirow[t]{2}{*}{ Catalyst } & \multirow[t]{2}{*}{$\begin{array}{l}\mathrm{Ce}^{3+} / \mathrm{Ni}^{2+} \\
\text { ratio }\end{array}$} & \multicolumn{2}{|c|}{$\begin{array}{l}\text { Ni dispersion } \\
(\mathrm{H} / \mathrm{M}),(\mathrm{Ni}) \mathrm{s} /(\mathrm{Ni})_{\mathrm{t}}\end{array}$} & \multicolumn{2}{|c|}{$\begin{array}{l}\text { TOF } \\
\text { (s site) }^{-1} \times 10^{3}\end{array}$} \\
\hline & & $\mathrm{A}$ & $\mathrm{B}$ & $\mathrm{A}$ & B \\
\hline 5 wt. $-\% \mathrm{Ni} / \mathrm{X}$ & 0 & 0.026 & 0.074 & 325 & 119 \\
\hline $5-2.5 \mathrm{Ni}-\mathrm{Ce} / \mathrm{X}$ & 0.21 & 0.023 & 0.104 & 127 & 28 \\
\hline $5-5 \mathrm{Ni}-\mathrm{Ce} / \mathrm{X}$ & 0.42 & 0.079 & 0.198 & 383 & 153 \\
\hline $5-10 \mathrm{Ni}-\mathrm{Ce} / \mathrm{X}$ & 0.84 & 0.058 & 0.140 & 1001 & 415 \\
\hline
\end{tabular}

Excluding the 5-2.5 Ni-Ce/X sample, it was found that the amount of hydrogen uptake showed a good correlation with the mean nickel crystallite size obtained by XRD. The decrease in nickel particle size due to the presence of cerium additive was evident. With $5-5 \mathrm{Ni}-\mathrm{Ce} / \mathrm{X}$ reduced at $300^{\circ} \mathrm{C}$, the nickel particle size was apparently too small (less than ca. $4 \mathrm{~nm}$ ) to be detected by XRD.

Generally, the BET surface area of the catalyst was not affected significantly by either the $\mathrm{Ce}^{3+}$ additives or a high reduction temperature. The smaller surface area of 5-10 Ni-Ce sample was suspected to be due to the blockage of some of the zeolite pores by $\mathrm{Ce}^{3+}$ cations or the possible forms of $\mathrm{CeO}_{\mathrm{x}}$.

The enhanced hydrogen chemisorption of the nickel zeolites due to the presence of cerium ions might be related not only to the smaller nickel particles, but also to the intrinsic properties of the cerium cations. In the present impregnated $\mathrm{Ni}-\mathrm{Ce} / \mathrm{X}$ samples it might be possible to produce cerium oxides (e.g., $\mathrm{CeO}_{2}, \mathrm{Ce}_{2} \mathrm{O}_{3}$ ) on the zeolite support. Ceria is known to take up hydrogen [15] at low reduction temperatures. As the metal dispersion was usually expressed by the $\mathrm{H}$-to- $\mathrm{M}$ ratio $\left(\mathrm{M}=\mathrm{Ni}^{\circ}\right)$, as deduced from hydrogen chemisorption by assuming one active surface nickel atom available per hydrogen atom. The deduced values are listed in column A in Table 4 . In the present instance these $\mathrm{H} / \mathrm{M}$ values might not correctly represent the metallic nickel dispersion owing to the possible electronic effect of $\mathrm{Ce}^{3+}$ cations or the hydrogen uptake by $\mathrm{CeO}_{2}$. The metallic nickel surface area was then calculated from the nickel particle size by assuming that the nickel crystallites were spheres and that all surface atoms were accessible. Thus, the following equation was established:

$S\left(\mathrm{~m}^{2} / \mathrm{g} \mathrm{Ni}\right)=6 \cdot 10^{1} /\left\{\left(8.91 \mathrm{~g} / \mathrm{cm}^{3}\right)[d(\AA)]\right\}$

where $d$ is the particle size in $\AA$ and $8.91 \mathrm{~g} / \mathrm{cm}^{3}$ is the density of nickel. Because $1 \mathrm{~m}^{2}$ of nickel surface corresponds to $1.54 \cdot 10^{19}$ atoms of nickel [16], the metallic nickel dispersion was then derived and expressed as the number of surface nickel atoms divided by the total number of nickel atoms in the sample: 
Ni dispersion $=(\mathrm{Ni})_{\mathrm{s}} /(\mathrm{Ni})_{\mathrm{t}}=10.112 / d(\dot{\mathrm{A}})$

The calculated results using the particle size of nickel obtained by XRD are listed in column B in Table 4 for comparison.

The nickel dispersion, or the fraction of active metallic nickel sites, obtained either from the hydrogen chemisorption or by XRD, was obviously affected by the $\mathrm{Ce}^{3+}$-to- $\mathrm{Ni}^{2+}$ ratio in the zeolites. The 5-2.5 Ni-Ce/X sample showed poor hydrogen chemisorption but exhibited significantly smaller nickel particles in comparison with the $5 \mathrm{wt} .-\% \mathrm{Ni} / \mathrm{X}$ catalysts. The reduced $5-5 \mathrm{Ni}-\mathrm{Ce} / \mathrm{X}$ sample showed smaller nickel particles and a better dispersion than the reduced $5-10 \mathrm{Ni}-\mathrm{Ce} / \mathrm{X}$ sample. It is concluded that the efficiency of the "chemical anchoring" by $\mathrm{Ce}^{3+}$ cations for nickel dispersion is very dependent on the $\mathrm{Ce}^{3+}$. to- $\mathrm{Ni}^{2+}$ ratio in zeolites. As the ratio of the radii of $\mathrm{Ni}^{2+}$ and $\mathrm{Ce}^{3+}$ is 0.445 , which is close to the $\mathrm{Ce}^{3+}-$ to- $\mathrm{Ni}^{2+}$ mole ratio in the $5-5 \mathrm{Ni}-\mathrm{Ce} / \mathrm{X}$ sample, it was suspected that one $\mathrm{Ce}^{3+}$ ion could supply approximately two anchoring sites to disperse nickel atoms in zeolites in the best situation.

The amount of hydrogen chemisorption did not correlate linearly with catalytic reactivity for carbon monoxide hydrogenation as referred to in Table 1. Efforts were made to use the turnover frequency (TOF) to express the catalytic activity. The turnover frequency is defined as the number of carbon monoxide molecules converted into the products per active site per second. The TOF for carbon monoxide hydrogenation over various $\mathrm{Ni}-\mathrm{Ce} / \mathrm{X}$ catalysts are also given in Table 4 . The results in columns A and B were calculated on the basis of the nickel dispersion deduced from hydrogen chemisorption and XRD, respectively. It was clear that, except for the $5-2.5 \mathrm{Ni}-\mathrm{Ce} / \mathrm{X}$, the TOF was enhanced by the addition of cerium no matter which basis of nickel dispersion was chosen.

Although the nickel dispersion of the impregnated samples was not as high as that of the reported ion-exchanged samples, the role of $\mathrm{Ce}^{3+}$ cations acting as anchoring points to disperse nickel in $\mathrm{X}$-reolite and to prevent the impregnated catalyst from sintering was conclusive. The relatively high reactivity for carbon monoxide hydrogenation over $5-10 \mathrm{Ni}-\mathrm{Ce} / \mathrm{S}$ catalyst was not only due to the high nickel dispersion but was also ascribed to the promotional characteristics of the cerium additives. In addition, the electron-donating properties of $\mathrm{Ce}^{3+}$ ions were proposed to initiate electron transfer towards the nickel metal, which would decrease the $\mathrm{C}-\mathrm{O}$ bond strength and thus increase the probability of $\mathrm{C}-\mathrm{O}$ bond dissociation and lead to the formation of high molecular weight hydrocarbons [5].

Temperature-programmed reduction (TPR) and desorption (TPD) of hydrogen

The TPR spectra for the samples with various cerium loadings are shown in Fig. 1. The diminution of the peak shoulder on the high-temperature side (HTS 


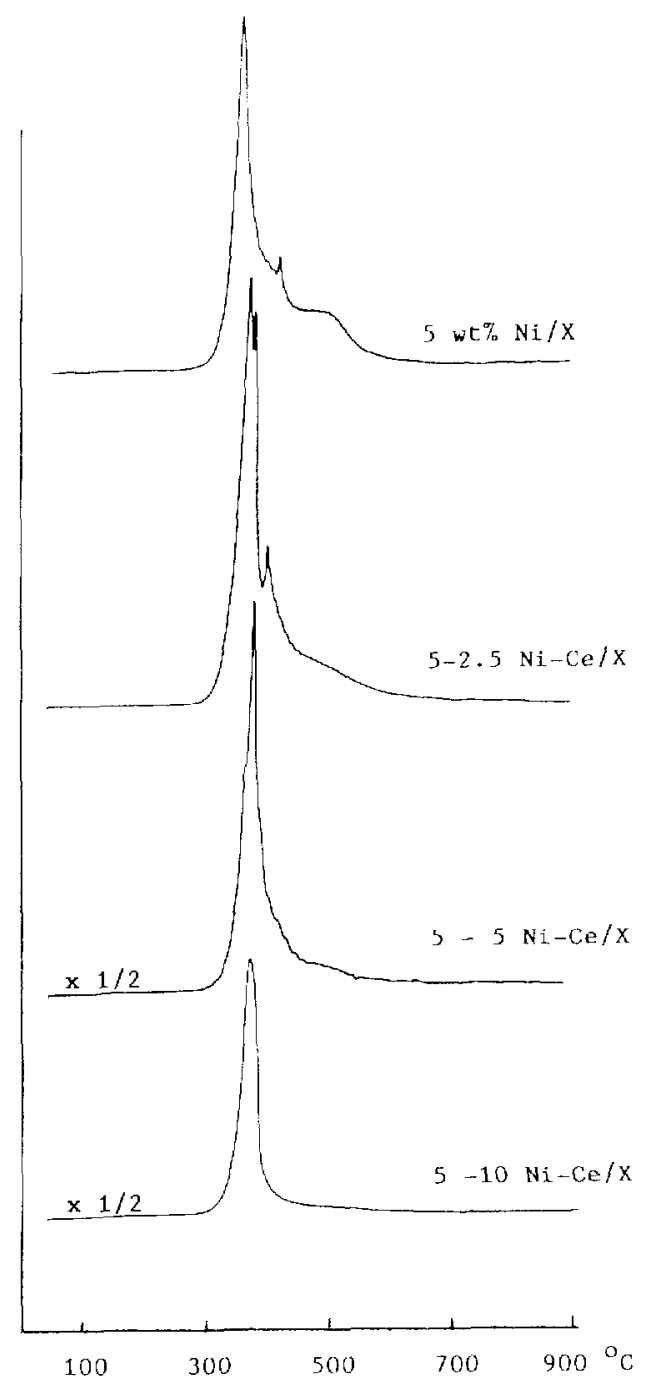

Fig. 1. Effect of $\mathrm{Ce}^{3+}$ additives on the TPR profiles for NiX zeolites. Carrier gas, $\mathrm{H}_{2}-\mathrm{Ar}(1: 10)$; flow-rate, $25 \mathrm{~cm}^{3} / \mathrm{min}$; heating rate $=10^{\circ} \mathrm{C} / \mathrm{min}$.

shoulder) between 400 and $500^{\circ} \mathrm{C}$ was substantial for these cerium-containing samples; this indicated that the reducibility of the catalyst was improved by the presence of cerium additives. These HTS shoulders on the TPR profiles were considered to be related to the reduction of the $\mathrm{Ni}^{2+}$ cations at $\mathrm{S}_{\mathrm{I}}$ sites inside the hexagonal prisms. According to Jeanjean et al. [9], there is a competition between $\mathrm{Ce}^{3+}$ and $\mathrm{Ni}^{2+}$ cations to occupy $\mathrm{S}_{\mathrm{I}}$ sites during the dehydration process. $\mathrm{Ce}^{3+}$ ions present in the impregnated samples would have priority 
to go into $\mathrm{S}_{\mathrm{I}}$ sites, leaving more $\mathrm{Ni}^{2+}$ ions on the accessible sites of zeolites, which resulted in a better reducibility and a better dispersion of nickel.

As the $\mathrm{Ce}^{3+}$ cations were added, the TPR peak maximum around $370^{\circ}$ split into two peaks and the consumption of hydrogen increased considerably. The splitting of the peak indicated that the reduction of nickel ions was accompanied by the reduction of cerium ions or by the interaction with cerium ions to stabilize nickel during the reduction process. By integrating the TPR peak area, it was found that the amount of hydrogen consumed by the 5 wt. $\% \mathrm{Ni}$ / $\mathrm{X}$-zeolite samples was close to the amount needed to reduce all $\mathrm{Ni}^{2+}$ ions to metallic $\mathrm{Ni}^{\circ}$ in the sample. As the content of the cerium additives increased, the hydrogen consumption also increased. In the samples of $5-5 \mathrm{Ni}-\mathrm{Ce} / \mathrm{X}$ and 5-10 Ni-Ce/X, the composition of hydrogen was even greater than would be needed for the reduction of all the $\mathrm{Ni}^{2+}$ ions to metallic $\mathrm{Ni}^{0}$ plus reduction of $\mathrm{Ce}^{4+}$ to $\mathrm{Ce}^{3+}$ ions. The present results suggest that hydrogen was dissociatively adsorbed on the reduced nickel particles with partial diffusion, and tenaciously retained on the zeolites during the reduction process, if the system contained cerium additives.

Fig. 2 shows the TPD spectra of hydrogen for various cerium-containing nickel zeolite catalysts. Each sample was previously reduced at $500^{\circ} \mathrm{C}$ for $3 \mathrm{~h}$ and cooled to room temperature under a hydrogen flow. Except for the 5-2.5 $\mathrm{Ni}-\mathrm{Ce} / \mathrm{X}$ sample, all the TPD profiles showed two peaks. The low-temperature (LT) peak was intensified by increasing the cerium content, whereas the high-temperature (HT) peak showed the opposite trend. We suggest that the LT peak corresponds to the true desorption of adsorbed hydrogen and the HT peak is due to the release of hydrogen by reoxidation of the $\mathrm{Ni}^{\circ}$ lacated in the small cages (sodalite cages or hexagonal prisms) of zeolite with lattice hydroxyl group. It has been reported by Jiang et al. [17] that metal atoms inside small zeolite cages are reoxidized more easily than metal clusters in the supercages or larger metal particles at the external surface. According to the TPD spectra in this study, more nickel particles were sustained in the sodalite cages or hexagonal prisms for the samples of $5 \mathrm{wt} . \% \mathrm{Ni} / \mathrm{X}$-zeolite and $5-2.5 \mathrm{Ni}-\mathrm{Ce} /$ $\mathrm{X}$. The finding agreed with the results for hydrogen chemisorption. The amount of desorbed hydrogen as referred to the LT peak seemed to be responsible for the catalytic activity of the catalyst for carbon monoxide hydrogenation.

Fig. 3 shows the TPD profiles of hydrogen for the $5-5 \mathrm{Ni}-\mathrm{Ce} / \mathrm{X}$ samples which were reduced at various temperatures. As the sample was reduced at $300^{\circ} \mathrm{C}$, the TPD spectra showed a large peak around $280^{\circ} \mathrm{C}$ (LT peak) with a small shoulder at $460^{\circ} \mathrm{C}$ (HT peak). When the reduction temperature was raised to $425^{\circ} \mathrm{C}$, the areas under the peaks increased and the centre of the HT peak shifted to $660^{\circ} \mathrm{C}$. On increasing the reduction temperature to $500^{\circ} \mathrm{C}$, the LT peak clearly decreased in intensity and the HT peak shifted to a higher temperature with increased intensity.

This was therefore in good agreement with the above assumption that the 


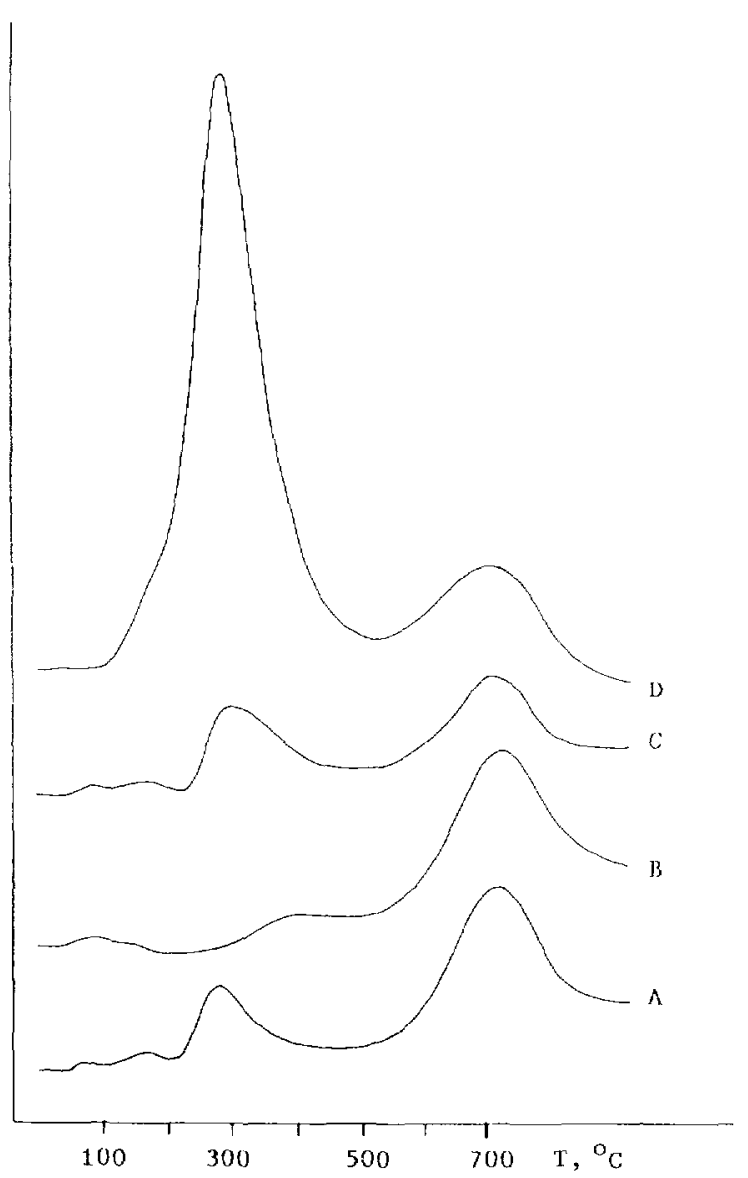

Fig. 2. Effect of $\mathrm{Ce}^{3+}$ additives on the TPD profiles for NiX zeolites. (A) 5 wt.- $\% \mathrm{Ni}$; (B) $5-2.5$ $\mathrm{Ni}-\mathrm{Ce}$; (C) 5-5 Ni-Ce; (D) 5-10 Ni-Ce. Carrier gas, Ar; flow-rate, $30 \mathrm{~cm}^{3} / \mathrm{min}$; heating rate $=19^{\circ} \mathrm{C} / \mathrm{min}$.

HT peak can be substantially ascribed to the release of hydrogen by the reoxidation of $\mathrm{Ni}^{\circ}$ with lattice hydroxyl groups in the small cages. The reaction might be given as

$2 \mathrm{Z}-\mathrm{OH}+\mathrm{Ni}^{0} \rightarrow \mathrm{Ni}^{2+}+\mathrm{H}_{2}+2 \mathrm{ZO}^{-}$

This reaction occurred at higher temperatures than the reduction of $\mathrm{Ni}^{2+}$ ions for the reverse reaction. The higher reduction temperature of the catalyst might cause more $\mathrm{Ni}^{0}$ species to be formed inside the small cages which were reoxidized. Hence the HT peak shifted to higher temperature with an enhanced peak intensity.

The activation energies of desorption of hydrogen were calculated to be about 6.5 and $26 \mathrm{kcal} / \mathrm{mol}$ corresponding to the LT and the HT peaks, respectively, 


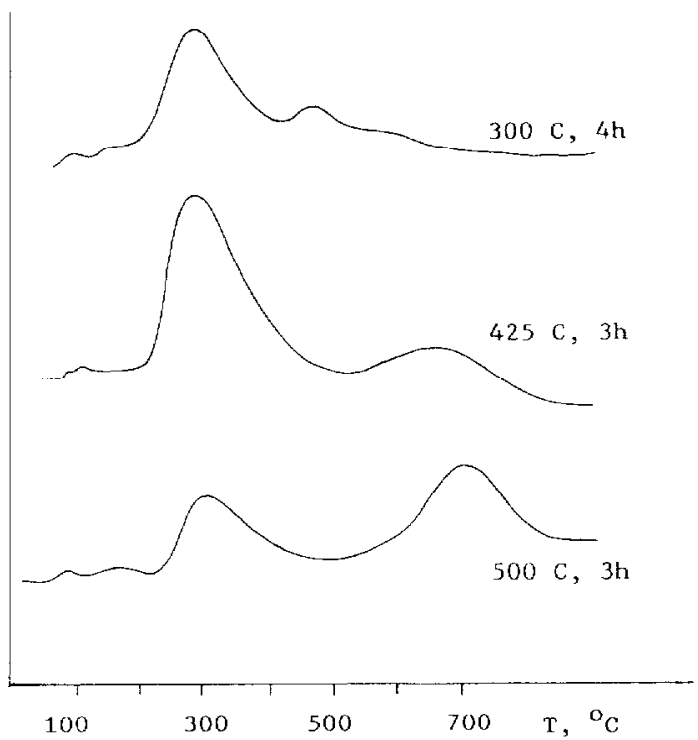

Fig. 3. TPD profiles of $5-5 \mathrm{Ni}-\mathrm{Ce} / \mathrm{X}$ reduced at various temperatures as indicated. Carrier gas, Ar; flow rate, $30 \mathrm{~cm}^{3} / \mathrm{min}$; heating ratc $=19^{\circ} \mathrm{C} / \mathrm{min}$.

of the TPD profiles of $5-10 \mathrm{Ni}-\mathrm{Ce} / \mathrm{X}$, by taking several TPD profiles at different heating rates following the method described by Thomas and Thomas [18]. It seemed reasonable that the LT peak represented the true desorption of adsorbed hydrogen and might be used to calculate the metal dispersion. Although precise quantitative analysis was difficult owing to the shifting in the background of the spectra, calculation of the relative number of active sites is still straightforward. The very high catalytic activity of $5-10 \mathrm{Ni}-\mathrm{Ce} / \mathrm{X}$ for carbon monoxide hydrogenation was due to the more accesible active sites which were anchored by the $\mathrm{Ce}^{3+}$ ions plus the available cerium ions acting as the catalyst promoter. Moreover, the larger surface hydrogen concentration could enhance the hydrogen assisted $\mathrm{C}-\mathrm{O}$ dissociation to initiate the reaction and to lead to the formation of high-molecular-weight hydrocarbons [19]. The higher activity of $5-5 \mathrm{Ni}-\mathrm{Ce} / \mathrm{X}$ reduced at $425^{\circ} \mathrm{C}$ compared with those reduced at 300 or $500^{\circ} \mathrm{C}$ could be due to the same reason. In contrast, the low activity of the $5-2.5 \mathrm{Ni}-\mathrm{Ce} / \mathrm{X}$ was mostly due to the lack of accessible active sites and the extremely low concentration of surface hydrogen.

We believe that the adsorption of carbon monoxide, usually dissociatively adsorbed on surface nickel or on the interface of $\mathrm{Ni}^{0}-\mathrm{Ce}^{3+}$ with the supporting oxide, was the primary factor for carbon monoxide hydrogenation. The effect of the ease of adsorption or desorption of hydrogen on the reactivity for carbon monoxide hydrogenation was not as sensitive as that for alkane hydrogenolysis. However, these studies indicated that there was a satisfactory correlation 
between the hydrogen TPD spectrum and the reactivity of carbon monoxide hydrogenation over the $\mathrm{Ni}-\mathrm{Ce} / \mathrm{X}$ catalysts. The surface hydrogen coverage of the reduced samples would be one of the important factors responsible for the reactivity and the selectivity of carbon monoxide hydrogenation over the $\mathrm{Ni}$ $\mathrm{Ce} / \mathrm{X}$ catalysts.

\section{Infrared spectra of carbon monoxide adsorption}

Adsorption of carbon monoxide was examined by in situ IR measurements. Fig. 4 shows the effects of $\mathrm{Ce}^{3+}$ additives on the IR spectra of carbon monoxide adsorption over various cerium-containing nickel/zeolite catalysts under a lowpressure atmosphere of carbon monoxide $\left(P_{\mathrm{CO}}=1\right.$ Torr $)$. Again, all the catalysts were reduced in hydrogen at $500^{\circ} \mathrm{C}$ for $3 \mathrm{~h}$ and evacuated at the same temperature before cooling to room temperature for carbon monoxide adsorption. Figs. $4 \mathrm{~A}$ and $4 \mathrm{~B}$ are the spectra recorded at the initial and the equilibrium states of carbon monoxide adsorption, respectively. The integrated peak area might be correlated with the accessibility of carbon monoxide to the catalyst.
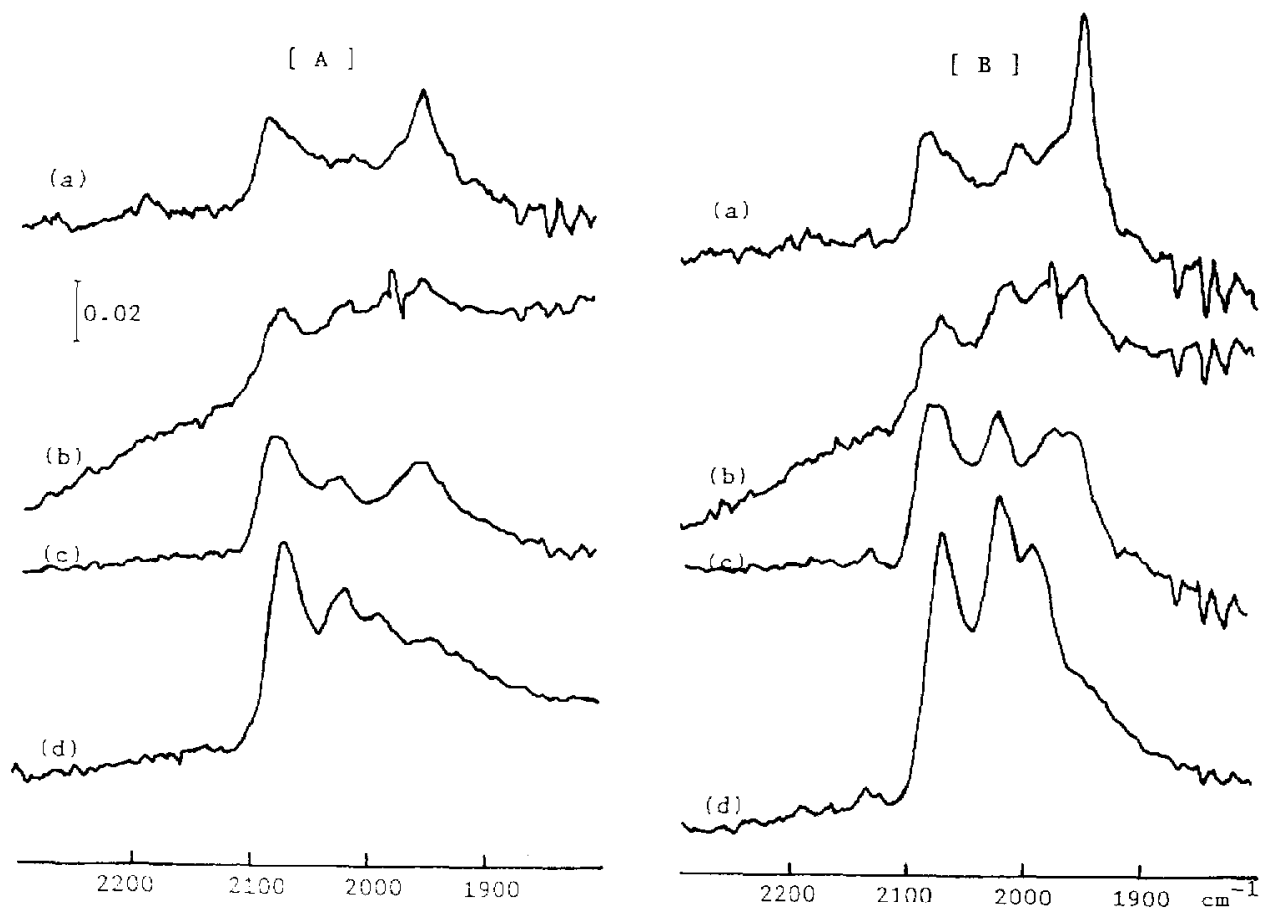

Fig. 4. Infrared spectra of adsorption of $\mathrm{CO}$ on X-zeolite-supported catalysts: (a) 5 wt.-\% Ni; (b) $5-2.5 \mathrm{Ni}-\mathrm{Ce}$; (c) 5-5 Ni-Ce; (d) 5-10 Ni-Ce. Spectra taken at (A) the initial and (B) equilibrium state of $\mathrm{CO}$ adsorption. $P_{\mathrm{CO}}=1$ torr. 
Obviously, the greater the number of accessible sites for carbon monoxide on the catalyst, the higher is the reactivity of the catalyst for carbon monoxide hydrogenation. The peak intensities were well correlated with the catalytic reactivities for carbon monoxide hydrogenation over the $\mathrm{Ni}-\mathrm{Ce} / \mathrm{X}$ catalysts. The peak assignments will be discussed elsewhere [20]. Briefly, the adsorption of carbon monoxide on the well dispersed $\mathrm{Ni} \mathrm{(ca.} 2080 \mathrm{~cm}^{-1}$ ) together with the easy migration of the bridged carbon monoxide form (ca. $1950 \mathrm{~cm}^{-1}$ ) might be responsible for the highest reactivity of carbon monoxide hydrogenation over the $5-10 \mathrm{Ni}-\mathrm{Ce} / \mathrm{X}$ catalyst. Further experiments showed that desorption of carbon monoxide from $\mathrm{Ni}-\mathrm{Ce} / \mathrm{X}$ is difficult at room temperature but is possible at $120^{\circ} \mathrm{C}$. In addition, the capability for re-adsorption of carbon monoxide ensured the stability of the active sites which led to the enhanced performance in carbon monoxide hydrogenation over the nickel zeolite catalysts in the presence of $\mathrm{Ce}^{3+}$ additives.

\section{Is there a strong metal-support interaction (SMSI)?}

As an SMSI state has been proposed to exist in the ion-exchanged $\mathrm{Ni}-\mathrm{Ce}$ / $\mathrm{X}$-zeolite catalysts to explain the suppression of hydrogen chemisorption and the unusual catalytic behaviour for carbon monoxide hydrogenation [5], it is interesting to review the problem for the present system. First, if there was an SMSI state existing in the $\mathrm{Ni}-\mathrm{Ce} / \mathrm{X}$ system, it would have to show a suppression of hydrogen chemisorption after high-temperature reduction (HTR) and the restorative ability of hydrogen chemisorption for the subsequent low-temperature reduction (LTR); the phenomenon would be reversible. The above criteria were used as an indicator for the SMSI catalyst [11]. In this study, as shown for the 5-5 Ni-Ce/X in Table 3, the capability of hydrogen chemisorption was hardly affected by the reduction temperature. Also, the addition of $\mathrm{Ce}^{3+}$ ions did not suppress but enhanced the hydrogen chemisorption for the HTR cerium-containing nickel zeolites. The results were obviously opposite to the unique features of the SMSI catalysts.

Despite the above conflict, we examined the reactivities of carbon monoxide hydrogenation over the HTR and LTR $5-5 \mathrm{Ni}-\mathrm{Ce} / \mathrm{X}$ samples. Sequential LTR and HTR was carried out at 300 and $500^{\circ} \mathrm{C}$, respectively (Fig. 5, curves 1 and 2 ). Subsequently, the catalyst was reoxidized in oxygen at $400^{\circ} \mathrm{C}$ for $1 \mathrm{~h}$ and an LTR was carried out at $300^{\circ} \mathrm{C}$ (curve 3 ), and finally an $\mathrm{HTR}$ was performed at $500^{\circ} \mathrm{C}$ (curve 4 ). The carbon monoxide hydrogenation was carried out over each reduced catalyst at $300^{\circ} \mathrm{C}$ with a hydrogen-to-carbon-monoxide flow-rate ratio of 3 . Fig. 5 illustrates the reversibility of the catalytic performance. The numbers 1,2 , etc., indicate the order of the sequential experimental measurements for carbon monoxide hydrogenation over the catalysts reduced under the indicated conditions as described above. It was interesting to find that the HTR sample showed a higher activity than the LTR sample. This catalytic behaviour was not the same as the performance of $\mathrm{Ni} / \mathrm{TiO}_{2}$ catalyst [20]. Ti- 


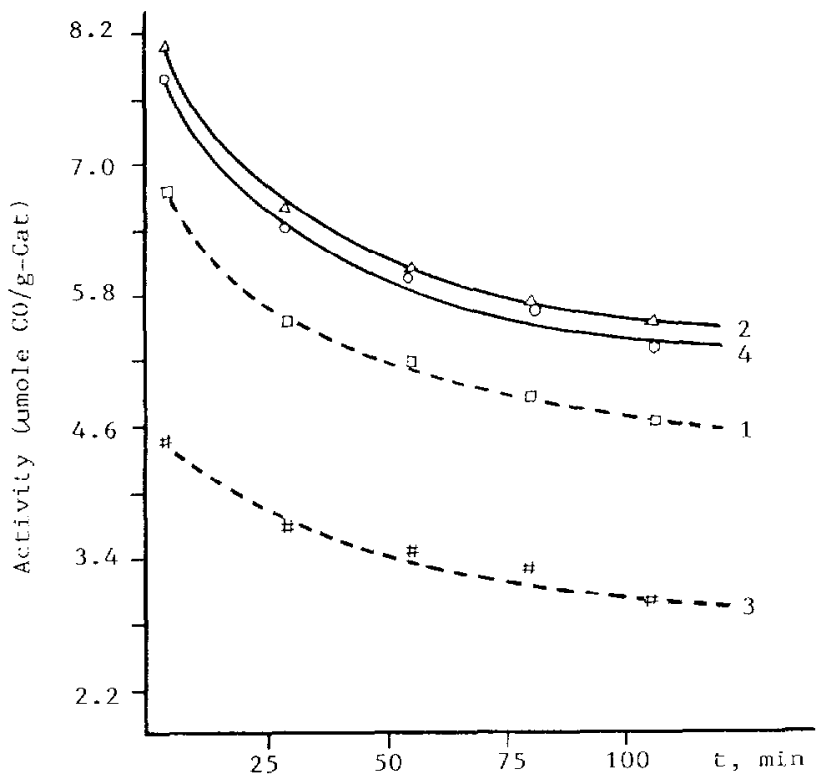

Fig. 5. Catalytic activity of 5-5 Ni-Ce/X for CO hydrogenation. sulid lines after HTR; dashed lines, after LTR; 1-4, sequential number of measurements.

tania is a typical oxide support for producing the so-called "SMSI" catalyst [11]. The enhanced activity for carbon monoxide hydrogenation and the shifting of the product to higher molecular weight hydrocarbons were characteristics of $\mathrm{Ni} / \mathrm{TiO}_{2}$ [21-23], but were not necessarily due to the presence of the SMSI state $[24,25]$. The reversibility of the HTR and LTR catalysts for carbon monoxide hydrogenation with the present $\mathrm{Ni}-\mathrm{Ce} / \mathrm{X}$ system might be attributed to the capability for reversible adsorption of carbon monoxide and the high resistance of nickel to sintering owing to the presence of cerium additives, as shown by the above IR experiments.

It seemed to be very difficult to correlate the $\mathrm{Ni}-\mathrm{Ce} / \mathrm{X}$ catalysts with the typical SMSI catalysts. However, it can be concluded that the cerium additives in the zeolite-supported nickel catalyst induced some kind of metal-support interactions which related to the "chemical anchoring" capability of cerium ions and prevented the catalyst from sintering.

\section{$X$-ray photoelectron spectroscopy}

X-ray photoelectron spectroscopy (XPS) was used to characterize the surface species of the catalysts. Fig. 6 shows the spectra for the unreduced 5-5 Ni$\mathrm{Ce} / \mathrm{X}$ catalyst and those after HTR and LTR treatments. The three signals from the low binding-energy side of each spectrum corresponded to the electrons of $\mathrm{Na}(3 \mathrm{~s}), \mathrm{Ni}(3 \mathrm{p})$ and $\mathrm{Al}(2 \mathrm{p})$. Apparently the concentration of surface 


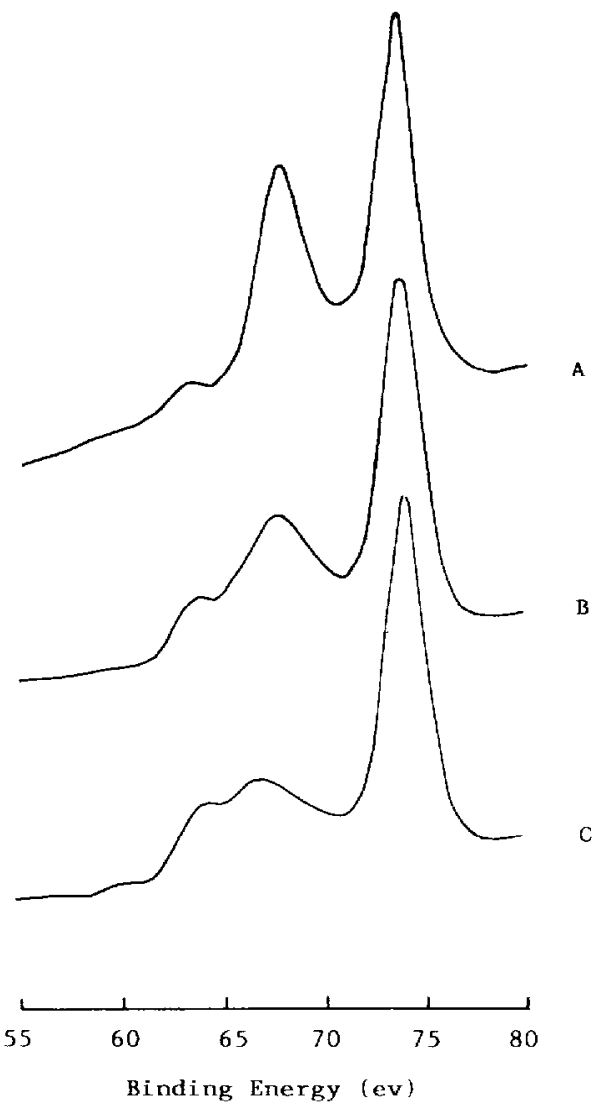

Fig. 6. X-ray photoelectron spectra of the $5-5 \mathrm{Ni}-\mathrm{Ce} / \mathrm{X}$ catalysts: (A) unreduced sample; (B) after LTR; (C) after HTR.

nickel was significantly decreased with peak shifting to the low binding-energy side after the high-temperature reduction. The lower binding energy of $\mathrm{Ni}$ ( $3 \mathrm{~s}$ ) indicated the enhancement of the electron density on the nickel species, possibly owing to the complete reduction of nickel or electron donation by cerium cations or the support. The concentration of surface $\mathrm{Na}^{+}$ions was simultaneously increased as the reduction temperature was increased. It has been suggested that the $\mathrm{Na}^{+}$ions located in the supercages could act as a screen for the $\mathrm{Ce}^{3+}-\mathrm{Ni}^{0}$ interactions and so enhance the migration of nickel species [4]. Hence the high reduction temperature produced larger particles of nickel.

Efforts have been made to verify the concentration and the oxidation state of surface cerium species in the active state of the catalyst, but the scattering in the high-energy background caused difficulties in obtaining the X-ray photoelectron spectra of cerium species. 


\section{CONCLUSION}

Owing to the electron-donating properties and the high polarizing field of $\mathrm{Ce}^{3+}$ cations, it is conceivable the $\mathrm{Ce}^{3+}$ ions modify the strength of the interaction between nickel and the zeolite support. It is concluded that the cerium additives in the zeolite-supported nickel catalysts, as prepared by incipientwetness impregnation in the study, acted as "chemical anchors" to the nickel dispersion and induced some kind of metal-support interaction which prevented the catalyst from sintering. The enhanced activity with the shift of the product selectivity to higher molecular weight hydrocarbons in carbon monoxide hydrogenation over $\mathrm{Ni}-\mathrm{Ce} / \mathrm{X}$ catalysts was essentially due to the presence of $\mathrm{Ce}^{3+}$ cations which led to the better reducibility of nickel, more accessible sites for carbon monoxide adsorption and a large surface concentration of hydrogen, which enhanced the hydrogen-assisted carbon monoxide dissociation during the reaction. The cerium cations act not only as chemical anchoring sites but also as catalyst promoters.

\section{ACKNOWLEDGEMENT}

We gratefully acknowledge financial support from the National Science Council of the Republic of China and are indebted to Ms. L.Y. Shao and Ms. Y.C. Chang for their assistance with part of the experiments. Thanks are also due to Dr. C.S. Fung and Ms. B.J. Lu of the Institute of Physics, Academia Sinica, for their assistance with the XPS measurements.

\section{REFERENCES}

1 B.J. Tatarchuk and J.A. Dumesic, J. Catal., 70 (1981) 308.

2 E.C.Akubuiro and X.E. Verykios, J. Catal., 103 (1987) 320.

3 M.S. Tzou, H.J. Jiang and W.M.H. Sachtler, Appl. Catal., 20 (1986) 231.

4 S. Djemel, M.F. Guilleux, J. Jeanjean, J.F. Tempere and D. Delafosse, J. Chem. Soc., Faraday Trans. I, 78 (1982) 835.

5 G.-N. Sauvion, J.-F. Tempere, M.-F. Guilleux, G. Djega-Mariadassou and D. Delafosse, J. Chem. Soc. Faraday Trans. I, 81 (1985) 1357.

6 M.F. Guilleux and D. Delafosse, J. Chem. Soc., Faraday Trans. I, 75 (1979) 165.

7 D. Delafosse, in B. Imelik, C. Naccache, Y. Ben Taarit, J.C. Vedrine, G. Goudurier and H. Praliaud (Eds.), Catalysis by Zeolites (Studies in Surface Science and Catalysis, Vol. 5), Elsevier, Amsterdam, 1980, p. 235.

8 G.-N. Sauvion, S. Djemel, J.-F. Tempere, M.-F. Guilleux, and D. Delafosse, in B. Imelik, C. Naccache, Y. Ben Taarit, J.C. Vedrine, G. Goudurier and H. Praliaud (Eds.), Catalysis by zeolite (Studies in surface Science and Catalysis, Vol. 5), Elsevier, Amsterdam, 1980, p. 245.

9 J. Jeanjean, S. Djemel, M.F. Guilleux and D. Delafosse, J. Phys. Chem., 85 (1981) 4145.

10 F. Vergand, B. Iraqi, C. Bonnelle, E. Ramaroson, M.-F. Guilleux, J.-F. Tempere and D. Delafosse, J. Chim. Phys., 83 (1986) 619.

11 S.J. Tauster, S.C. Fung and R.L. Garten, J. Am. Chem. Soc., 100 (1978) 170. 
12 S.H. Chien, K.L. Lu and H.W. Huang, J. Chin. Chem. Soc., 32 (1985) 309.

13 H.P. Klug and L.E. Alexander, X-ray Diffraction Procedures for Polycrystalline and Amorphous Materials, 2nd ed., Wiley, New York, 1974, p. 491.

14 S.H. Chien, L.Y. Shao and Y.R. Chiou, Bull. Inst. Chem. Acad. Sin., 35 (1988) 53.

15 J.L.G. Fierro, J. Soria, J. Sanz and J.M. Rojo, J. Solid State Chem., 66 (1987) 154.

16 J.R. Anderson, Structure of Metallic Catalysts, Academic Press, New York, 1975, p. 296.

17 H.J. Jiang, M.S. Tzou and W.H.M. Sachtler, Catal. Lett., 1 (1988) 99.

18 J.M. Thomas and W.J. Thomas, Introduction to the Principles of Heterogeneous Catalysis, Academic Press, New York, 1975, p. 110.

19 C.C. Kao, S.C. Tsai and Y.W. Chung, in B. Imelik, C. Naccache, G. Goudurier, H. Praliaud, P. Meriaudeau, P. Gallezot, G.A. Martin and J.C. Vedrine (Eds.), Metal-Support and MetalAdditive Effects in Catalysis (Studies in Surface Science and Catalysis, Vol. (11), Elsevier, Amsterdam, 1982, p. 211.

20 S.H. Chien and Y.C. Chang, to be published.

21 M.A. Vannice and R.L. Garten, J. Catal., 56 (1979) 236.

22 C.H. Bartholomew, R.B. Pannell and J.L. Butler, J. Catal., 65 (1980) 335.

23 C.H. Bartholomew and C.K. Vance, J. Catal., 91 (1985) 78.

24 R. Burch and A.R. Flambard, J. Catal., 85 (1984) 16.

25 S.A. Stevenson, J.A. Dumesic, R.T.K. Baker and E. Ruckenstein (Eds.), Metal-Support Interactions in Catalysis, Sintering, and Redispersion, van Nostrand Reinhold, New York, 1987,55 . 